\title{
Tanggung Jawab Notaris Dalam Penyimpanan Akta In Originali Sebagai Minuta Akta
}

\section{Theresia Gst Agung Indah Utari Dewi ${ }^{1}$, Nyoman A.Martana ${ }^{2}$}

\author{
${ }^{1}$ Program Studi Magister (S2) Kenotariatan, Fakultas Hukum Universitas Udayana, \\ E-mail: theresiaindahutari@gmail.com \\ ${ }^{2}$ Fakultas Hukum Universitas Udayana, Email: nyoman_martana@unud.ac.id
}

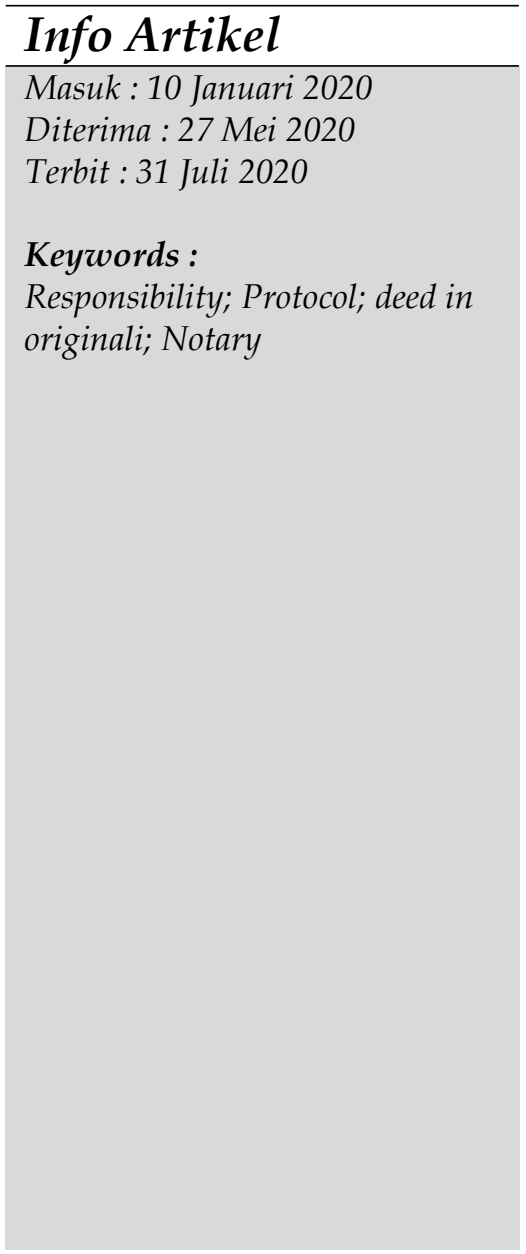

\begin{abstract}
The purpose behind this paper is to understand the implementation in practice related to depositing the deed in originali as a minuta deed at the Notary's office and the responsibility of the notary related to the deposit of the deed in originali as a deed minuta. The method to researching this problem is using empirical juridicial. This research uses an approach in law that is an approach using a statutory regulation (The Statue Approach) and an approach by looking at the facts that occur in the field (The Fact Approach). There are two supporting data which is Interviews data as primary data and literature, laws, and books as Secondary data. Qualitative descriptive analysis technique used in this study as a analysis technique. Compiling data collected systematically after all data has been collected both of them. The results of the discussion obtained show that (1) Implementation in practice of depositing the deed in originali as a minuta deed at the Notary Office is wrong, for example, the deed of Power of Attorney Imposing Mortgage Rights (SKMHT). SKMHT made by Notary / PPAT in practice is made all original in originali in two copies. One deed in originali is kept as part of a collection of Notary protocols as minuta, another deed in originali is given to the authorized person. The purpose of keeping the deed in originali as a minuta is as an archive or document by a Notary Public, in addition to that in binding the deed minuta bundle, the numbers of the minuta deactivate sequentially. (2) Notaries are still responsible for keeping the deed in originali as a minuta deed, because it is a State document, so it is obligatory for each Notary to maintain and store it in a good place, so that it is not easily damaged, disappeared or lost.

Abstrak
\end{abstract}




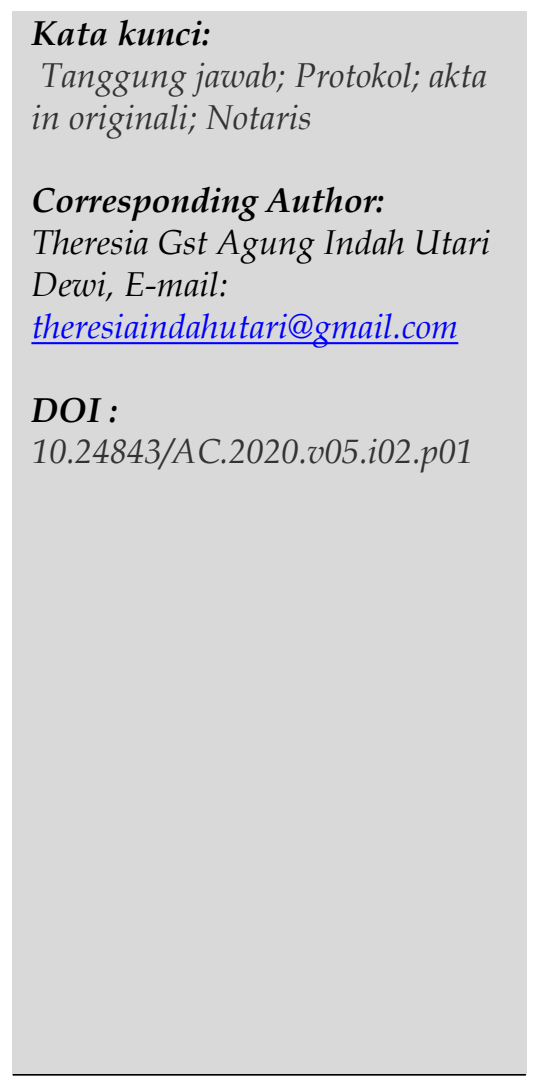

\begin{abstract}
Tujuan dalam penulisan ini adalah untuk mengetahui dan menganlisis mengenai implementasi terkait penyimpanan akta in originali sebagai minuta akta di kantor Notaris dan tanggung jawab oleh notaris terkait disimpannya akta in originali sebagai minuta akta. Jenis penelitian yuridis empiris sebagai metode dalam permasalahan penelitian ini. Data primer bersumber dari wawancara dan data sekunder bersumber dari literature, buku-buku, maupun undang-undang. Teknik analisis yang digunakan dalam penelitian ini ialah teknik kualitatif Kesimpulan yang diperoleh menunjukkan bahwa (1) Pelaksanaan dalam praktek terhadap penyimpanan akta in originali sebagai minuta akta di kantor Notaris salah contohnya akta Surat Kuasa Membebankan Hak Tanggungan (SKMHT). SKMHT yang dibuat oleh Notaris/PPAT dalam prakteknya tersebut dibuat semuanya asli in originali dalam dua rangkap. Satu lembar akta in originali disimpan sebagai bagian dari kumpulan protokol Notaris sebagai minuta, satu lembar akta in originali lagi diberikan kepada penerima kuasa. (2) Notaris tetap bertanggungjawab terhadap penyimpanan akta in originali sebagai minuta akta, karena merupakan dokumen Negara sehingga wajib oleh setiap Notaris memelihara dan menyimpan ditempat yang baik, agar tidak mudah rusak, lenyap ataupun hilang.
\end{abstract}

\section{Pendahuluan}

Suatu profesi yang menjalankan tujuan dari negara yaitu menjamin ketertiban, kepastian serta perlindungan hukum dengan menciptakan suatu alat bukti yang bentuknya tertulis yaitu akta autentik merupakan profesi seorang Notaris. Menciptakan akta autentik merupakan suatu kewenangan dari Notaris, sepanjang tidak diberikan kewenangan tersebut kepada pejabat lain sebagaimana sumber kewenangan Notaris diatur dalam Undang-Undang Nomor 30 Tahun 2004 tentang Jabatan Notaris (selanjutnya disebut dengan UUJN) maupun Perubahan UUJN yaitu Undang-Undang Nomor 2 Tahun 2004 (selanjutnya disebut dengan UUJN-P). Notaris diklasifikasikan melakukan perbuatan melanggar hukum apabila dikemudian hari menjalankan suatu kewenanganannya diluar batas wewenang yang telah diaturnya didalam UUJN maupun UUJN-P,sehingga memiliki pertanggungjawaban moral terhadap tindakannya tersebut. ${ }^{1}$

Selain terdapat kewenangan, terdapat juga suatu keharusan yaitu kewajiban yang dijalankan oleh seorang Notaris, karena telah diatur didalam UUJN maupun UUJN-P. Membuatkan akta dalam bentuk minuta akta dan menyimpan akta tersebut sebagai salah satu bagian kumpulan dari Notaris merupakan suatu kewajiban yang harus dilaksanakan Notaris sebagaimana telah diatur dalam Pasal 16 ayat 1 huruf b UUJN-P. ${ }^{2}$ Namun di dalam Pasal 16 ayat 2 UUJN-P tidak ada suatu keharusan bag notaris

${ }^{1}$ Putra, A. P. (2019). TANGGUNG JAWAB NOTARIS TERHADAP AKTA YANG CACAT SECARA FORMAL. JURTAMA, 1(1), 1-11.

2 Suwardiyati, Rumi. "Konsekuensi Yuridis Minuta Akta yang Tidak Dimiliki Notaris dalam Pembuatan Salinan Akta." Kumpulan Jurnal Mahasiswa Fakultas Hukum (2015). 
untukmenyimpan akta in originali sebagai minuta akta di kantor Notaris sebagaimana diatur dalam UUJN maupun UUJN-P sehingga asli akta diberikan kepada para pihak dan Notaris tidak mempunyai suatu keharusan untuk menyimpan akta in orginali tersebut sebagai minuta akta.

Pada prakteknya, meskipun didalam UUJN maupun UUJN-P tidak mewajibkan untuk menyimpan minuta akta in originali, akan tetapi umumnya Notaris menyimpan akta in orginali sebagai minuta. Tujuan untuk menyimpan minuta akta in originali yaitu sebagai arsip atau dokumen oleh Notaris. Dalam pelaksanaanya bahwa salah satu dari jenisjenis akta in originali yang sering disimpan sebagai minuta akta oleh seorang Notaris yaitu Akta Surat Kuasa Membebankan Hak Tanggungan (SKMHT) yang merupakan salah satu surat yang dibuatkan oleh seorang Notaris atau oleh seorang Pejabat Pembuat Akta Tanah (PPAT) yang berisikan suatu kuasa, dimana seorang pemberi kuasa memberikan kuasa kepada pemegang kuasa untuk membebankan hak tanggungan terhadap hak atas suatu tanah dan/atau hak milik atas suatu satuan rumah susun yang akan dijadikan jaminan utang. Berdasarkan penjabaran dari latar belakang masalah, terdapat suatu masalah yang dapat diangkat yaitu bagaimanakah pelaksanaan dalam praktek terkait penyimpanan akta in originali sebagai minuta akta di kantor Notaris dan bagaimanakah pertanggung jawaban seorang Notaris terkait disimpannya akta in originali sebagai minuta akta.

Tujuan dalam penulisan ini yakni untuk mengkaji tentang pelaksanaan dalam praktek bagaimanakah pelaksanaan dalam praktek terkait penyimpanan akta in originali sebagai minuta akta di kantor Notaris dan menganlisis mengenai bagaimanakah pertanggung jawaban seorang Notaris terkait disimpannya akta in originali sebagai minuta akta.

\section{Metode Penelitian}

Metode penelitan yang dipergunakan dalam penelitian ini yakni metode penelitian yuridis empiris. Metode penelitian hukum yuridis empiris yaitu penelitian yang menekankan penelitiannya pada implementasi ketentuan suatu aturan perundangundangan dalam penerapannya yang terjadi dalam suatu masyarakat ${ }^{3}$. Dasar yang digunakan untuk meneliti permasalahan adalah aturan perundang-undangan, setelah itu melakukan analisis dilakukan penelitian mengenai fakta yang terjadi dilapangan. Data yang didapatkandilapangan dengan melakukan wawacara langsung dengan orang-orang yang memiliki hubungan secara langsung dengan permasalahan penelitian diklasifikasikan sebagai data primer sedangkan data yang didapat dalam undangundang dan buku-buku penunjang diklasifikasikan sebagai data sekunder. Penelitian ini dengan menggunakan teknik deskriptif kualitatif sebagai teknik analisis, dengan cara mengumpulkan data-data baik primer dan sekunder, kemudian peneliti mengolah ,menganalisis serta menyusun data kemudian peneliti akan mengubungkan satu data dengan data lainnya, setelah itu dilaksanakan interpretasi dan dilaksanakan penafsiran.

\footnotetext{
${ }^{3}$ Elizabeth Nuhaini ButarButar, 2018, Metode Penelitian Hukum, Refika Aditama, Jakarta, h. 96
} 


\section{Hasil dan Pembahasan}

\subsection{Implementasi Terkait Penyimpanan Akta In Originali Sebagai Minuta Akta Di Kantor Notaris}

Pada dasarnya, Notaris mempunyai suatu kewajibannya salah satunya adalah menyimpan kumpulan protokol Notaris, salah satu diantaranya adalah minuta akta. Akan tetapi kewajiban ini dikecualikan apabila Notaris mengeluarkan akta in originali. Untuk akta in originali , dimana asli akta diberikan kepada para pihak dan Notaris tidak ada keharusan untuk mengarsipkan minuta akta kedalam bundel minuta akta.

Pieter EL mengemukakan pengertian tentang akta in originali yaitu : "Asli akta yang diberikan kepada yang langsung berkepentingan dalam akta dan akta in originali ini tidak disimpan dalam Protokol Notaris, sehingga untuk akta dalam in originali, Notaris tidak dapat mengeluarkan salinan akta kutipan akta dan grosse akta". ${ }^{4}$

Yudo Diharjo Lantanea berpendapat akta in originali ialah : "salah satu akta kuasa dimana asli akta diserahkan oleh Notaris kepada pihak pembuat kuasa dapat dibuat sebanyak para pihak perlukan, dan pada setiap akta terdapat ketentuan berlaku sebagai satu dan satu berlaku untuk semua". Sehingga misalnya Notaris membuat 2 (dua) rangkap maka sejumlah itu saja diberikan kepada para pihak, apabila Notaris mengeluarkan akta in originali, Notaris tidak ada kewajiban untuk menyimpan minuta akta ke dalam bundel akta notaris bulanan walaupun dimasukan kedalam buku daftar Notaris (repertorium) dan diberi nomor bulanan. Dalam akta terdapat seluruh tanda tangan dan paraf para penghadap dan terdapat catatan pinggir (renvooi). Akta in originali dapat dibuatkan sebanyak yang diperlukan oleh para pihak. Notaris dalam prakteknya membuat 1 (satu) rangkap agar dapat disimpan sebagai salah satu bagian protokol Notaris sehingga apabila para pihak memerlukan suatu hari arsip dari akta in originali , maka Notaris akan memberikan fotokopi terhadap akta in originali kepada para pihak. Akta in originali hanya dapat dibuatkan dalam 1(satu) rangkap apabila kuasa tidak dilengkapi nama dari yang memberikan kuasa". ${ }^{5}$

Akta dapat diklasifikan sebagai akta in originali, jika syarat-syarat terpenuhi yang terdapat dalam UUJN meliputi :

1. Akta in originali dapat dibuatkan lebih dari 1 (satu) jika para pihak menghendaki dan akta bersama-sama ditandatangani oleh para pihak, para saksi yaitu karyawan Notaris serta seorang Notaris pada saat waktu yang sudah ditentukan dengan bentuk serta isi yang sama.

2. Setiap akhir akta terdapat kalimat : "berlaku sebagai satu dan satu berlaku untuk semua".

3. Hanya boleh dibuatkan dalam 1 (satu) rangkap apabila kuasa itu belum dilengkapi oleh nama dari yang memberi kuasa.

4. Apabila penghadap sudah terlebih dahulu membaca kemudian memahami isinya pembacaan akta tidak harus untuk dilakukan, jadi di dalam penutup akta harus terdapat pernyataan oleh para penghadap kemudian oleh setiap penghadap

\footnotetext{
${ }^{4}$ H.Salim HS, 2016, Teknik Pembuatan Akta Satu (Konsep Teoretis, Kewenangan Notaris, Bentuk dan Minuta Akta), Cetakan kedua, PT. RajaGrafindo Persada, Jakarta, h. 154

${ }^{5}$ H.Salim HS, Op.Cit, h. 154
} 
diparaf,selanjutnya diparaf untuk tiap-tiap halaman minuta aktanya oleh saksi dan Notaris

Ketentuan mengenai syarat-syarat dibuatnya akta in orgininali didalam UUJN telah diatur, apabila tidak terpenuhi salah satu syarat-syaratnya maka akta in originali mempunyai kekuatan pembuktian dibawah tangan. ${ }^{6}$ Terdapat enam jenis yang termasuk akta in originali: ${ }^{7}$

1. Akta yang berisi pembayaran untuk uang sewa, bunga serta pensiun, yang dapat dijabarkan menjadi :

a. Akta pembayaran untuk uang sewa

Yaitu akta yang terdapat klausula pelunasan yang dilakukan dari pihak penyewa terhadap pihak menyewakan, karena pihak penyewa akan menikmati objek sewa, terhadap barang bergerak ataupun barang tidak bergerak.

b. Akta pembayaran bunga

Merupakan akta yang memuat klausula mengenai kesepakatan para pihak dalam hal penggunaan uang atau modal.

c. Akta pembayaran uang pensiun

Merupakan akta yang memuat klausula mengenai pembayaran pelunasan sejumlah dana tunjangan kepada karyawan atau pegawai yang sudah pensiun, dimana pembayaran pelunasan ini diberikan tiap-tiap bulannya.

2. Akta yang berisi penawaran untuk melakukan pembayaran tunai

Yaitu akta yang terdapat klausula mengenai pelunasan oleh si berutang kepada si berpiutang secara tunai.

3. Akta yang berisi protes terhadap surat berharga yang tidak diterima atau tidak dibayar.

Yaitu akta yang terdapat klausula pernyataan tidak dilunasi atau tidak diberikan surat berharga dari pemberi surat berharga kepada penerima surat berharga.

4. Akta yang berisi kuasa

Merupakan akta yang berisikan kuasa mengatasnamakan orang yang memberikan kuasa dalam hal untuk melaksanakan sesuatu kepada yang penerima suatu kuasa.

5. Akta keterangan kepemilikan,dan

Merupakan akta yang memuat mengenai uraian tentang kepemilikan seseorang atas sesuatu benda yang dimilikinya. Dalam hal ini benda yang dimilikinya yaitu benda yang tidak bergerak maupun bergerak.

6. Akta lainnya yang sudah ditentukan dalam peraturan perundang-undangan

Akta lainnya ini tidak disebutkan secara jelas dalam UUJN maupun UUJN-P yang diklasifikasikan sebagai akta in originali.

Berdasarkan wawancara bersama Notaris/PPAT di Kabupaten Badung yaitu Dr. Ida Bagus Agung Putra Santika, SH,M.Kn bahwa memang Notaris tidak memiliki kewajiban

\footnotetext{
${ }^{6}$ H.Salim HS, Op.Cit, h. 159

${ }^{7}$ H.Salim HS, Op.Cit, h. 156-157
} 
untuk menyimpan akta in originali sebagai minuta akta di kantor Notaris sebagaimana di atur dalam UUJN maupun UUJN sehingga asli akta diberikan kepada para pihak dan tidak mempunyai suatu keharusan untuk menyimpan akta in orginali tersebut sebagai minuta akta. Namun dalam pelaksanaan prakteknya akta in originali yang disimpan oleh Notaris sebagai minuta akta dikantor Notaris, salah contohnya akta SKMHT merupakan kuasa yang wajib dibuatkan oleh Notaris/PPAT yang berisikan kekuasaan dari yang memberikan kuasa kepada yang menerima kuasa untuk membebankan hak tanggungan terhadap hak atas suatu tanah dan/atau hak milik atas satuan rumah susun yang nantinya akan menjadi jaminan utang. SKMHT dalam pelaksanaan prakteknya dibuatkan dalam 2 (dua)lembar yang semuanya asli in originali, yang ditandatangani oleh yang memberikan suatu kuasa dan yang menerima suatu kuasa, para saksi yaitu karyawan dari Notaris dan seorang Notaris ataupun PPAT yang membuatnya. Satu lembarnya dalam bentuk minuta akta disimpan dikantor Notaris/PPAT yang bersangkutan yang dijilid dalam satu bendel minuta dan satu lembar lagi diserakan untuk yang menerima suatu kuasa sebagai kebutuhan nantinya dalam pembuatan dari Akta Pembebanan Hak Tanggungan (APHT). Dalam pelaksanaan prakteknya disimpannya akta in originali sebagai minuta akta mempunyai tujuan yaknin sebagai arsip atau dokumen oleh Notaris selain itu agar dalam penjilidan bundel minuta akta, nomer minuta aktanya berurutan, selain itu UUJNP tidak melarang dan tidak memberi sanksi untuk pembuatan akta in originali lebih dari satu, sehingga Notaris boleh saja membuat akta in orginali lebih dari 1 (satu) apabila para pihak menghendaki untuk dibuatnya lebih dari 2 (satu)dan disimpan akta in originali dalam bentuk minuta, sebagai arsip atau dokumen. Dibuatnya lebih dari 1 (satu) dengan bentuk dan isi yang sama dan ditandatangani oleh para pihak, kemudia karyawan dari Notaris yang menjadi saksi dan seorang Notaris.

\subsection{Tanggung Jawab Notaris Terkait Disimpannya Akta In Originali Sebagai Minuta Akta}

Notaris memiliki kewenangan yang melekat dalam jabatannya. Kewenangan yang terdapat dalam jabatannya ini melahirkan suatu pertanggungjawaban, yang searah dengan prinsip umum "gee bevoegheid zonder verantwoordelijkheid" yaitu tiada kewenangan tanpa pertanggungjawaban" ${ }^{8}$ Kewenangan yang terdapat dalam jabatan Notaris melahirkan suatu pertanggungjawaban bagi seorang pejabat Notaris.

Berdasarkan pendapat dari ahli hukum yaitu Paul F.Camanisch, bahwa kelompok suatu profesi mempunyai kekuasaan bertindak atas nama pribadi dan mempunyai pertanggungjawaban secara spesifik atas tindakannya. Suatu kelompok profesi mempunyai dasar bagi mereka dalam menjalani jabatannya yang disebut dengan Kode Etik Profesi. ${ }^{9}$ Notaris sebagai bagian dari kelompok profesi dalam menjalani suatu jabatannya memiliki pertanggungjawaban atas setiap tindakan atas nama jabatannya.

Notaris dalam berwenang membuat akta autentik yaitu diatur dalam Pasal 15 ayat 1 sampai dengan ayat 3 UUJN-P yaitu :

8 Mido, Muhammad Tiantanik Citra, I. Nyoman Nurjaya, and Rachmad Safa'at. "Tanggung Jawab Perdata Notaris terhadap Akta yang Dibacakan oleh Staf Notaris di Hadapan Penghadap." Lentera Hukum 5.1 (2018): 156-173.

${ }^{9}$ Yandillah, Ariy. "Tanggung Jawab Notaris Pengganti Terkait Pembuatan Akta Notaris Yang Merugikan Para Pihak Akibat Kelalaianya." Kumpulan Jurnal Mahasiswa Fakultas Hukum (2015). 
"Notaris berwenang membuat akta autentik mengenai semua perbuatan, perjanjian, dan penetapan yang diharuskan oleh peraturan perundang-undangan dan/atau yang dikehendaki oleh yang berkepentingan untuk dinyatakan dalam akta autentik, menjamin kepastian tanggal pembuatan akta, menyimpan akta, memberikan grosse, salinan dan kutipan akta, semuanya itu sepanjang pembuatan Akta itu tidak juga ditugaskan atau dikecualikan kepada pejabat lain atau orang lain yang ditetapkan oleh undang-undang".

Selain wewenang seorang Notaris untuk melaksanakan pembuatan akta otentik dapat melakukan tindakan hukum tertentu sebagaimana termasuk dalam kewenangan khusus. Kewenangan secara khusus ini seperti :

1. Melaksanakan tindakan pengesahan tanda tangan para pihak dan menentukan kejelasan waktu dalam hal terkait untuk surat yang dibuat secara dibawah tangan selanjutnya mencatatnya didalam suatu buku khusus.

2. Melaksanakan tindakan dengan cara membukukan terkait dengan surat-surat yang dibuat secara dibawah tangan selanjutnya mencatat didalam suatu buku khusus.

3. Melaksanakan tindakan dengan cara membuat Salinan berdasarkan asli surat-surat yang dibuat dibawah tangan yang memuat suatu uraian sebagaimana tertulis dalam surat yang dibuat secara dibawah tangan.

4. Melaksanakan tindakan pengesahan terhadap kecocokan kopi surat berdasarkan asli dari suratnya.

5. Melaksanakan tindakan kepada para penghadap yaitu memberikan suatu penyuluhan hukum yang ada kaitannya dengan proses pembuatan suatu akta

6. Melaksanakan tindakan dengan membuat suatu akta yang ada hubungannya dengan bidang pertanahan,.

Kewajiban serta kewenangan melahirkan suatu tanggung jawab. Kewajiban dan kewenangan lahir semenjak Notaris telah mengucapkan sumpah jabatannya sebagai Notaris, sehingga Notaris harus berpedopam pada aturan yang berlaku dalam menjalankan suatu jabatannya.

Berdasarkan wawancara bersama dengan Notaris/PPAT di Kabupaten Badung yaitu Notaris Dr. Ida Bagus Agung Putra Santika, SH, M.Kn Notaris tetap mempunyai suatu tanggung jawab terkait setiap akta yang sudah dibuatnya walaupun didalam UUJN tidak mewajibkan untuk menyimpan akta in originali sebagai bagian dari kumpulan Protokol Notaris, tetapi tanggung jawab itu tetap melekat kepada Notaris sebagaimana sudah ditegaskan dalam Pasal 65 UUJNP bahwa "Notaris, Notaris Pengganti, dan Pejabat Sementara Notaris bertanggung jawab atas setiap akta yang dibuatnya meskipun protokol Notaris telah diserahkan atau dipindahkan kepada pihak penyimpan protokol Notaris." Pertanggungjawaban Notaris terkait penyimpanan akta in originali yang disimpan minuta aktanya sebagai bagian dari kumpulan protokol Notaris dapat diklasifikasikan dalam berbagai segi yaitu : tanggung jawab hukum secara administrasi, secara perdata dan secara pidana, sebagaimana diuraikan yaitu :

a. Tanggung jawab hukum terkait administrasi 
Pertanggungjawaban secara administrasi ini terkait pelanggaran administrasi yang sudah ada dalam Pasal 85 UUJN yang menentukan sanksi administratif terkait melakukan pelanggaran yang terdapat didalam Pasal tersebut ${ }^{10}$. Teguran yang dilakukan secara lisan maupun teguran yang dilakukan secara tertulis, pemberhentian yang dilaksanakan dengan sementara, pemberhentian yang dilaksanakan dengan hormat ataupun pemberhentian yang dilaksanakan secara tidak hormat yakni sanksi secara administrasi yang dapat dibebankan kepada Notaris.

b. Tanggung jawab hukum secara perdata

Pertanggungjawaban ini terkait apabila Notaris melaksananakan suatu pelanggaran yang memberikan kerugian untuk para pihak. Seorang Notaris dapat bertanggung jawab secara perdata sebagaimana telah ditentukan dalam UUJN yaitu Pasal 84. Tanggung jawab ini dapat berupa pemberian suatu biaya berupa kerugian yang diterima akibat terkait tindakan dari Notaris yang memberikan kerugian kepada para pihak dan juga kerugian terkait akta yang dibuatnya mempunyai kekuatan pembuktian menjadi akta yang dibawah tangan ataupun akta tersebut menjadi batal demi hukum. ${ }^{11}$

c. Tanggung jawab hukum secara pidana oleh Notaris

Didalam UUJN maupun UUJN-P tidak diatur terkait pelanggaran dari seorang Notaris dalam klasifikasi sebagai tindakan pidana. Jadi setiap Notaris tunduk terhadap aturan pada Kitab Undang-Undang Hukum Pidana (selanjutnya disingkat KUHP). Sanksi secara pidana untuk seorang Notaris, yang berhubungan dengan proses pembuatan akta autentik ditentukan secara umum di dalam ketentuan KUHP pada Pasal 266. Klasifikasi tindakan pidana dalam pembuatan akta otentik terkait dalam memalsukan keterangan palsu, baik keterangan secara lisan mapun tertulis yang mengandung unsur ketidak benaran yang seolaholah benar yang kemudian sengaja dipergunakan di dalam pembuatan akta autentik. Ancaman pidana tersebut berlaku sama jika siapapun dengan sengaja menggunakan akta tersebut sehingga menyebabkan suatu kerugian terhadap orang lain. ${ }^{12}$

\section{Kesimpulan}

Pelaksanaan prakteknya akta in originali yang disimpan oleh Notaris sebagai minuta akta dikantor Notaris, salah contohnya akta SKMHT merupakan kuasa yang wajib dibuatkan oleh Notaris/PPAT yang berisikan kekuasaan dari yang memberikan kuasa kepada yang menerima kuasa untuk membebankan hak tanggungan terhadap hak atas suatu tanah dan/atau hak milik atas satuan rumah susun yang nantinya akan menjadi jaminan utang. SKMHT dalam pelaksanaan prakteknya dibuatkan dalam 2

\footnotetext{
${ }^{10}$ KURNIASIH, F. Y. Tanggung Jawab Notaris Atas Kebenaran Isi Akta Partij..

11 Afifah, Kunni. "Tanggung Jawab dan Perlindungan Hukum bagi Notaris secara Perdata Terhadap Akta yang Dibuatnya." Lex Renaissance 2.1 (2017): 10.

${ }^{12}$ Fitriyeni, Cut Era. "Tanggung Jawab Notaris terhadap Penyimpanan Minuta Akta sebagai Bagian dari Protokol Notaris." KANUN: Jurnal Ilmu Hukum 14.3 (2012): 391-404.
} 
(dua)lembar yang semuanya asli in originali, yang ditandatangani oleh yang memberikan suatu kuasa dan yang menerima suatu kuasa, para saksi yaitu karyawan dari Notaris dan seorang Notaris ataupun PPAT yang membuatnya. Satu lembarnya dalam bentuk minuta akta disimpan dikantor Notaris/PPAT yang bersangkutan yang dijilid dalam satu bendel minuta dan satu lembar lagi diserakan untuk yang menerima suatu kuasa sebagai kebutuhan nantinya dalam pembuatan dari Akta Pembebanan Hak Tanggungan (APHT). Notaris tidak memiliki kewajiban untuk menyimpan akta in originali sebagai minuta akta di kantor Notaris sebagaimana di atur dalam UUJN maupun UUJN sehingga asli akta diberikan kepada para pihak dan tidak mempunyai suatu keharusan untuk menyimpan akta in orginali tersebut sebagai minuta akta, apabila disimpan oleh Notaris sebagai minuta akta Notaris, Notaris tetap mempunyai pertanggungjawaban terhadap penyimpanan sebagaimana seperti minuta akta pada umumnya. Selain itu pertanggungjawaban oleh N.

\section{Daftar Pustaka}

Buku

Elizabeth Nuhaini ButarButar, 2018, Metode Penelitian Hukum, Refika Aditama, Jakarta.

H.Salim HS, 2016, Teknik Pembuatan Akta Satu (Konsep Teoretis, Kewenangan Notaris, Bentuk dan Minuta Akta), Cetakan kedua, PT. RajaGrafindo Persada, Jakarta.

Ridwan HR , 2014, Hukum Administrasi Negara, Edisi Revisi, Grafindo Persada, Jakarta.

\section{Jurnal}

Afifah, Kunni. "Tanggung Jawab dan Perlindungan Hukum bagi Notaris secara Perdata Terhadap Akta yang Dibuatnya." Lex Renaissance 2.1 (2017): 10.

Fitriyeni, Cut Era. "Tanggung Jawab Notaris terhadap Penyimpanan Minuta Akta sebagai Bagian dari Protokol Notaris." KANUN: Jurnal Ilmu Hukum 14.3 (2012): 391-404.

KURNIASIH, F. Y. Tanggung Jawab Notaris Atas Kebenaran Isi Akta Partij.

Mido, Muhammad Tiantanik Citra, I. Nyoman Nurjaya, and Rachmad Safa'at. "Tanggung Jawab Perdata Notaris terhadap Akta yang Dibacakan oleh Staf Notaris di Hadapan Penghadap." Lentera Hukum 5.1 (2018): 156-173.

Putra, A. P. (2019). TANGGUNG JAWAB NOTARIS TERHADAP AKTA YANG CACAT SECARA FORMAL. JURTAMA, 1(1), 1-11.

Suwardiyati, Rumi. "Konsekuensi Yuridis Minuta Akta yang Tidak Dimiliki Notaris dalam Pembuatan Salinan Akta." Kumpulan Jurnal Mahasiswa Fakultas Hukum (2015).

Yandillah, Ariy. "Tanggung Jawab Notaris Pengganti Terkait Pembuatan Akta Notaris Yang Merugikan Para Pihak Akibat Kelalaianya." Kumpulan Jurnal Mahasiswa Fakultas Hukum (2015). 